mental Responses"' (with chapters on breathing, food and feeding, thermoregulation and water balance, activity and seasonal dormancy); "Communication" (sensory receptors and perception, signals); and "Population Phenomena" (reproduction, growth, community and population density). Here again, there are sections that have little to do with natural history. For example, the details of the structure and ventilation of the bird's lung and airsac system are merely functional anatomy, and only become natural history if comparative data are given on variations in the structure or relative size of the system in different birds, such as penguins, ostriches, humming birds and so on. The book is also not without errors: for example, hagfish do not have only a single pair of gills (p.104), and the spiracle is not the vestigial last gill (p.106).

Nevertheless, those wishing to flesh out structural anatomy with interesting examples of natural history will find many useful examples in this book, and there is an extensive bibliography of well over 1,000 entries.

Barry Cox is a Professor of Zoology at King's College, University of London.

\title{
The welcome return of J.Z. Young
}

\section{Beverly Halstead}

The Life of Vertebrates, 3rd Edn. By J.Z. Young. Pp.645. Hbk ISBN 0-19-857172-0; pbk ISBN 0-19-857173-9. (Oxford University Press: 1981.) Hbk £25, \$26.95; pbk £14. The Chordates, 2nd Edn. By R. McNeill Alexander. Pp.510. Hbk ISBN 0-521-23658-4; pbk ISBN 0-521-28141-5. (Cambridge University Press: 1981.) Hbk $£ 35, \$ 69.50$; pbk $£ 12.50, \$ 24.95$. Lecture Notes on Vertebrate Zoology. By R. Pearson and J.N. Ball. Pp.180. Pbk ISBN 0-632-00729-X. (Blackwell Scientific/ Halsted: 1981.) £7.50, \$21.95. Anatomy of the Chordates, 4th Edn. By C.K. Weichert. Pp.814. ISBN 0-07-069007-3. (McGrawHill: 1981.) $\$ 37.75$, 220.95 .

IN 1950 J.Z. Young published The Life of Vertebrates, which rapidly came to dominate the teaching of vertebrate zoology at a time when the vertebrates occupied an entire academic year in most zoology degree courses. In 1962 the second edition appeared, but by the end of the 1960s and throughout the 1970s there was no J.Z. and teachers were obliged to look elsewhere. Not only that, but vertebrate zoology had to relinquish much of its territory as newer aspects of biology rose to the fore. Vertebrate courses became a catalogue of anatomy, with long names to be studied and learnt for no other apparent reason than that it was supposed to do students good. The vertebrates tended to be relegated to a smaller and smaller part of the curriculum. As this process was underway, by some curious irony advanced texts, monographs and symposium volumes on the group seemed to be constantly pouring out of publishing houses; yet there was nothing remotely suitable in the way of a general textbook.

In 1975 there appeared McNeill Alexander's The Chordates, a general textbook of vertebrate zoology written by a leading expert in biomechanics, which in many ways fitted the bill. Here, the structures of the vertebrates were discussed from the standpoint of their mechanics.
This approach lent itself especially to practical demonstration of the basic principles involved and was a truly excellent contribution to teaching, though the mathematical aspects tended to intimidate both the students and the less numerate teachers. However, this textbook signalled a refreshing new approach that deserved encouragement. The publication of a second edition, which has been updated and includes several new topics such as a useful discussion of dinosaur biomechanics, augurs well for the future of vertebrate zoology and the biomechanical approach being promoted by Alexander.

The appearance of Pearson and Ball's Lecture Notes on Vertebrate Zoology clearly fills a need in the teaching scheme of things. It is sad that it should be so. This book as far as one can judge sets out to record all the boring bits of the subject, with its emphasis on pure anatomy. The authors' aim ' "to release the teacher from the drudgery of simply reproducing anatomy and to create a platform for profitable expansion on innumerable other topics"'. Well, here is the drudgery all right but $I$ fear that having created this platform, far from inspiring a prospective student into "profitable expansion" it would convince him that the subject is one of stupefying boredom to be avoided at all cost. The illustrations are notable for their variable quality: the crude sketch of the structure of a reptile scale (p.93) conveys nothing to me, and I suspect the authors would not have included it had they ever looked at a microscopic section of, say, lizard skin. Worse, some of the information is so out of date that it would appear that the authors have cobbled together their material from a selection of older textbooks. I suppose a teacher could use the book to instruct students in some basic information but they would be failing in their duty to allow students a glimpse of it. This book can only do harm in that it is guaranteed to snuff out any spark of enthusiasm.

Last year also saw the appearance of the fourth edition of Weichert's Anatomy of the Chordates, a system by system comparison of the chordates - a worthy, albeit rather fusty book, again dating from a time (1951) when the vertebrates formed a larger proportion of the syllabus than today. This book, however, can be recommended for all teachers of vertebrate zoology in that it is relatively easy to pick out how, for instance, the vascular system varies from one major structural grade of vertebrate to another. This is the kind of book to have to hand as a reference for teaching.

For teachers and students of vertebrate zoology the publishing event of 1981 was, however, the long awaited return of J.Z. Young, with the third edition of The Life of Vertebrates. It all comes back now, why J.Z. had such a profound effect on both teachers and students; here he speaks directly to the reader about really fascinating topics. It is always possible to complain that the choice of topics is rather too personal but this is surely what gives the book its vitality. The notable thing about The Life of Vertebrates is that a mass of information is communicated in such a light and easy manner; but, more important, the enthusiasm of youth pervades this book. There are odd bits where one cannot help but be irritated because it is either grossly out of date or

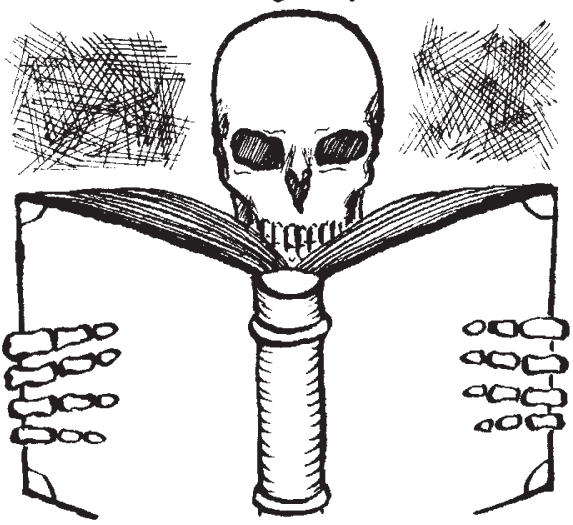

plain wrong, such as the hopelessly inaccurate diagram of the visceral arches and jaws in early vertebrates. One of the greatest surprises is that the current controversies on methods of classification and the arguments over the process of evolution and the fossil record are alluded to and the clear voice of common-sense always characterizes J.Z.'s overview, not only of current fashions but of the place of zoology in its wider perspective.

The pre-eminent position of J.Z. Young as the teacher and enthusiast of the study of the vertebrates is richly deserved. This is the best textbook around. The occasional lapses can be forgiven; it is the inspiration that he provides that will encourage a new generation to come into vertebrate zoology.

L.B. Halstead is Reader in Geology and Zoology at Reading University and Research Fellow in Anatomy at the Royal Dental Hospital of London. 